\title{
Water Treatment and Purification in Fiqh Perspective
}

\author{
Wan Ainaa Mardhiah Wan Zaharia ${ }^{a}$, Arwansyah Kirin ${ }^{b}$, Norhafizah Ahmad ${ }^{\mathrm{c}}$, Siti Marpuahd ${ }^{\mathrm{d}}$, and Nur \\ Zainatul Nadra Zainol ${ }^{\mathrm{e}}$
}

Islamic Studies Department, Centre of General Knowledge and Co-curricular, University of Tun Hussein Onn Malaysia, Johor.

Article History: Received: 11 January 2021; Accepted: 27 February 2021; Published online: 5 April 2021

\begin{abstract}
Water is the primary source needed to ensure human and other creature life continuity. There are a lot of water on this planet, but increasingly this water is not where it is needed or it is of inadequate quality (purity) for human consumption or other beneficial for example industrial, agricultural and so on purposes. Contaminated water supply causing harm to human body health and also contributes to extinction to the certain creature. Thus, water-saving or wise water usage is an important matter in Islam. Reuse of wastewater or sewage water is a solution to the water crisis problem faced nowadays. The contaminated water is purified and treated by certain processes. Water purification or treatment water is introduced to produce pure and clean water. However, discussions and debates among experts and societies continue to occur because the water is categorised as pure water but not purify (musta'mal) and impure water and not purify (mutanajjis). Therefore, this study aims to identify the concept and method of water purification and treatment (تطهير الماء) according to Fiqh perspective. Methodology of this study is qualitative approach by using document analysis by analysing several classic Fiqh books by four mazhab (Hanafi, Maliki, Shafie and Hanbali). Hence, this study can discover the water purification method suggested in Fiqh perspective to be applied by Muslim communities in Malaysia.
\end{abstract}

Keywords: Water, Purification, Treatment, Fiqh, Four Mazhabs

\section{Introduction}

Water occupies a pivotal role in Islam and is recognized by Muslims as a blessing that purifies humankind and earth. The Arabic word for water is ma'a (ماء) referenced exactly 63 times in Al-Quran and recurring topic in many hadith of the Prophet Muhammad s.a.w (Abdul Baqi, 1987). Al-Quran has been clearly mention the importance of water for human life:

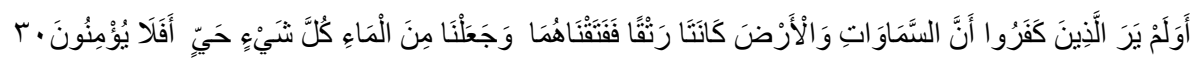

Have those who disbelieved not considered that the heavens and the earth were a joined entity, and We separated them and made from water every living thing? Then will they not believe?

(Al-Quran. Al-Anbiya' 21:30)

In Malaysia context, a level of system and water management is considered to be among the best in this region with the reservoir and water catchment systems and the rivers are still functioning to supply the water needs (Ahmad Zaharuddin, 2004). But, the water crisis in 1998 and also contaminated and dried rivers in Malaysia shows the condition of water source in Malaysia is threatened. According to Datuk Seri Dr. Wan Junaidi Tuanku Jaafar, Minister of Natural Resources \& Environment said that there are 10 polluted and contaminated rivers in Malaysia that shows a big number that need to be counter and handle as it not be worsen. Hence, the efforts of the Department of Irrigation and Drainage to restore and revive these contaminated rivers should be implemented immediately to ensure the water supply in this country will not be affected in the future (Ranhill Cons, 2011). The saying of Bahá's Great Parakrama, Sri Lanka's King of the 12th century that:

"Do not allow even a drop of rainwater to flow into the sea without benefitting the people".

Most of all wastewater and sewage water from residential, urban and industrial areas flows back into the natural environment without being treated or reused. This causes pollution to existing water quality. In this regard, waste water treatment methods were introduced to solve the problem.

Due to the water shortage, the usage of treatment or reclamation water is introduced in several countries. Though, the acceptability among the users is an obstacle towards this action due to the several factors such as disgust or 'yuck' factor, specific reclaimed water application like toilet flushing versus bathing, sources of water to be recycled which are from greywater and blackwater and so on (Kirsten \& Troy, 2012). In addition, Muslim users also have distinctive objected towards the usage of treatment water as it is not permissible especially for religious grounds. These factors comes from the lacking of knowledge. It can be seen from the acceptability of South Africa users when e Thewe municipal consider to introduce the usage of reclamation water as supplement 
to existing potable water resources (Abdelkadir Ismail et al, 2015) and also the acceptability of Singapore residents towards Newater sourced from wastewater to be drink.

Hence, the method of treatment and purification water is invented to avoid wasted water and conserve the nature. There are many treatment methods used today in industries to reuse the water and it is permissible and accepted in science perspective as not harmful for the body healthy. But are these methods applied nowadays in line with Islamic guideline? So, this study is to determine and then suggest the best method of treatment and purification water in line with Fiqh perspective.

\section{Concept of Water}

The water is synonym to cleanliness or taharah in Islam. The Arabic word for purification is taharah that literally means purity and from an Islamic view, this term refers to a state of cleanliness, which Muslim must be in to perform certain acts of worship (Walid Abderrahman, 2000).

Taharah is a specified method of cleansing which is conditional for the validity of solah (pray). There are two types of cleanliness (Umar, 2015):

i. Cleanliness from hadath - invisible impurity

Cleans oneself for performing wudu' (ablution), ghusl (bath) or tayammum

ii. Cleanliness from khabath - visible impurity

Clean oneself after istinja' and remove impurity from human body, clothes and place of prayer

Next, things that can be used for cleansing (mutahhirat) can be divided into four, which are clean water, clean soil, clean stone and currying (skin) (Faruqui et al, 2011). Here, the importance of water can be seen as the one of the tool for cleansing in Islam.

Water is profound importance in Islam and all human beings rely on water for life and good health for Muslims, it enjoys special importance for its use in wudhu' (ablution) and ghusl (bathing).

\subsection{Water Use and Water Usage}

Discussion on water use and water usage is crucial to be highlighted because these two subjects are related to water quality and this water quality standard is differenced and depending to the use and usage of water (Istajib \& Raihanah, 2012).

Water is the given and favour from Allah that leading human to hasanah in this world and also hasanah akhirah that needs to be managed properly and wisely as it will be questioned by Allah later in akhirah (Nooh Gadot, 2002). So, the wise management and usage of water is very important to be practised because these will affected the water quality. As the effort to control the water quality, Islam have teaches the believer about the akhlak (manner) and ethics towards the water usage rationally and fairly. Al Quran has concluded about the water uses in the follows verses;

Table 2.1: Water Use in Al Quran Perspective

\begin{tabular}{l|l|l}
\hline No. & \multicolumn{1}{c}{ Water Uses } & \multicolumn{1}{c}{ Surah } \\
\hline & $\begin{array}{l}\text { Humans and animals drinks } \\
\text { Nourish the plants } \\
\text { Al-Waqi'ah (56:17-21) }\end{array}$ \\
\hline $\begin{array}{l}\text { (self, clothes \& shelter) and spiritual (shaitan's } \\
\text { disturbance) }\end{array}$ & $\begin{array}{l}\text { Al-Muddathir (74:4) } \\
\text { Al-Anfal (9:11) }\end{array}$ \\
\hline & $\begin{array}{l}\text { Nourish the nature, greening the landscape \& balancing } \\
\text { the ecosystems }\end{array}$ & $\begin{array}{l}\text { Al-Nahl (16:65) } \\
\text { Al-Rum (30:24) } \\
\text { Al-Hajj (22:63) }\end{array}$ \\
\hline & $\begin{array}{l}\text { Source of livelihood through economic activities } \\
\text { agriculture, farming \& fishery) }\end{array}$ & $\begin{array}{l}\text { Al-Baqarah (2:22) } \\
\text { Al-Jathiyah (45:12) } \\
\text { Al-Ma'idah (5:96) }\end{array}$ \\
\hline & $\begin{array}{l}\text { Regional and international communication medium } \\
\text { Development of knowledge }\end{array}$ & Al-Mulk (67:30) \\
\hline
\end{tabular}


Source: Istajib et al (2012)

According to the table above, it shown that the priority to be given in water uses application; starting with the human uses, then for animal uses and lastly for agriculture purposes (Walid, 2000).

Next, from the water usage perspective, there are varieties of naqli dalils mention about the management of water usage.

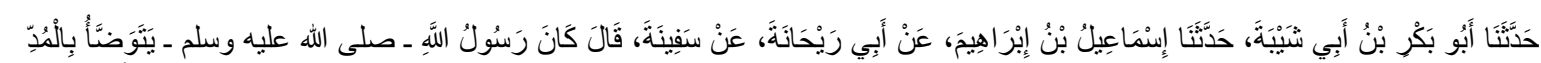

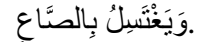

It was narrated that Safinah said: "The Messenger of Allah used to perform ablution with a Mudd (of water) and bath with a Sa'."

(Al-Hadith. Sunan Ibn Majah. Kitab At-Toharah wa Sunanuha. Book 1, \#279)

Next, dalil from al-Quran also mention how to act with water wisely as follows:

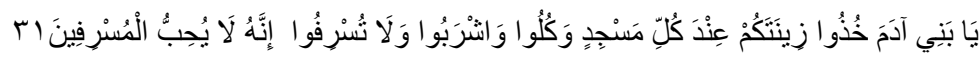

O children of Adam, take your adornment at every masjid, and eat and drink, but be not excessive. Indeed, He likes not those who commit excess.

(Al-Quran. Al-A'raf. 7:31)

The prophet Muhammad s.a.w. has shown the best example and role model for human in managing the water wisely.

\section{Methodology}

The qualitative method is applied in this study by using document analysis approach. Researcher using two sources of data in this research which are primer and secondary data. For gain more data in this research related to the latest water treatment and purification process, researcher use document analysis to gain data related to fuqaha' opinions toward water treatment and purification process by referring to the kitab (books) and documents related to the research topic. These books and documents are accested by using computer and library research. The data is gained by using library research and document analysis.

\section{Findings}

Finding for this study is concluded for several sub topic as follows:

\subsection{Classification of Water in Islam}

There are varieties of views for the classification of water among the fuqaha' such as Imam Hanafi, Imam Maliki, Imam Syafie and Imam Hanbali. Views from contemporary scholars and researchers also have been discussed in this chapter.

\subsubsection{Hanafi Mazhab}

Hanafi was divided the water into five types as follows (al-Zuhaily, 1994):

i. Pure water, can be purified and not makruh

ii. Pure water, can be purified and makruh

iii. Pure water and cannot be purified

iv. Mutanajjis water

v. Pure water and cannot be purified

vi. Water is in doubt of its purity

\subsubsection{Maliki Mazhab}

Imam Malik mentions that water classified into three types; which are used for religion purposes like ghusl hadath and ablution and for daily life purposes like bathing, watering, drinking and so on as follows (al-Zuhaily, 1994): 
i. Pure water itself and purify to others

(Rainwater, sea water and springs or wells)

ii. Pure water itself but does not purify the others

iii. Impure Water

\subsubsection{Syafie Mazhab}

Syafie was divided the water into five types as follows (al-Zuhaily, 1994):

i. Pure water and can purify others

ii. Pure water and can purify others but makruh to be used

iii. Pure water but cannot purify others

iv. Impure water

Mustafa Al-Khin, et al (1989) also has classified water into four groups as follows:

i. Water which is clean itself and can be used for cleansing

(This water is mutlaq water)

ii. Water which is clean itself but makruh to used for cleansing

(This water is musyammas water with certain conditions)

iii. Water which is clean itself cannot be used for cleansing

iv. Water which is polluted

\subsubsection{Hambali Mazhab}

Hambali was divided the water into two types only as follows (Ibn Taimiyah, 1987):

i. Tahur

ii. Najas

\subsubsection{Contemporary Fiqh Scholars}

Contemporary Fiqh scholars and majority of scholars (jumhur fuqaha') classified water into three groups which are tahur, tahir and najas (Al-Zuhaily, 1985). The details information as mention in table below:

Table 4.1: Water Characteristic of its Classifications

\begin{tabular}{lll}
\hline Classification of Water & Nature/ Characteristic of Water & \\
\hline & Pure in nature & Can be used for purification \\
\hline Tahur & Yes & Yes \\
\hline Tahir & Yes & No \\
\hline Najas & No & No \\
\hline
\end{tabular}

Source: Ibn Taimiyyah (1987)

Mutlaq water is tahur (pure) in nature and can be used for cleansing likes rain water, sea water, dawn water, well water and also snow. The quantity of this water is not taken into account if it is in the original place, but it should exceed two (2) qullah if it has been used or stagnant. The aspects nature change and the application of water is as follows:

Table 4.2: Mutlaq Water Classification

\begin{tabular}{llll}
\hline $\begin{array}{l}\text { Mutlaq Water } \\
\text { Classification }\end{array}$ & \multicolumn{1}{c}{ I } & II & III \\
\hline Water & No water quantity is & More than two (2) qullah & Less and small quantity \\
Quantity & determined if taken & if water has been used or & \\
(Amount) & from seven mutlaq & stagnated & \\
& water sources. & &
\end{tabular}




\begin{tabular}{|c|c|c|c|}
\hline $\begin{array}{l}\text { Water } \\
\text { Characteristic } \\
\text { Change }\end{array}$ & $\begin{array}{l}\text { Water retains its } \\
\text { original nature and has } \\
\text { no change in smell, } \\
\text { colour and taste. }\end{array}$ & $\begin{array}{l}\text { There is a change but still } \\
\text { maintains its nature } \\
\text { (tahur). }\end{array}$ & $\begin{array}{l}\text { There is no change in the } \\
\text { nature of water, whether in } \\
\text { smell, colour or taste but } \\
\text { has been drunk by animals }\end{array}$ \\
\hline \multirow[t]{2}{*}{$\begin{array}{l}\text { Water } \\
\text { Application }\end{array}$} & $\begin{array}{l}\text { Najasah purification } \\
\text { Eliminate the najasah. }\end{array}$ & & $\begin{array}{l}\text { The hukm of its use is } \\
\text { makruh tanzih if there is } \\
\text { another alternative }\end{array}$ \\
\hline & Utilized for all uses & & \\
\hline
\end{tabular}

Source: Istajib and Raihanah (2012)

Musta'mal water is also included in the category of pure water in nature but cannot be used for cleansing. This water refers to the water that has been used for purification such as ablution, wajib bath and cleanse of najasat in quantities that are not up to two (2) qullah. Musta'mal water is classified into three categorise as below:

Table 4.3: Musta'mal Water Classification

\begin{tabular}{cccc}
\hline $\begin{array}{c}\text { Types of Water } \\
\text { Water Quantity } \\
\text { (Amount) }\end{array}$ & Musta'mal & Musta'mal Muqayyad & Musta'mal Mukhalit \\
\hline $\begin{array}{c}\text { Water Characteristic } \\
\text { Change }\end{array}$ & $\begin{array}{c}\text { No change on smell, } \\
\text { colour and taste but the } \\
\text { water have been reused } \\
\text { for purification of } \\
\text { najasah, cleaning and so } \\
\text { on }\end{array}$ & $\begin{array}{c}\text { Change on one of smell, } \\
\text { colour or taste when the } \\
\text { water mixed with the } \\
\text { pure element and can be } \\
\text { consumed like syrup or } \\
\text { tea }\end{array}$ & $\begin{array}{c}\text { Change on one of smell, } \\
\text { colour or taste when the } \\
\text { water mixed with the } \\
\text { non-essential element } \\
\text { and cannot be consumed } \\
\text { like moan. }\end{array}$ \\
\hline
\end{tabular}

Water Application

Remove the haqiqi najasah only and not hukmi najasah.

Not allowed to use for religious purposes

Source: Istajib and Raihanah (2012)

Table 4.4: Mutanajjis Water Classification

\begin{tabular}{lll}
\hline Water Quantity (Amount) & Less than two (2) qullah & More than two (2) qullah \\
\hline Water Characteristic Change & $\begin{array}{l}\text { No change on odour, colour and change on odour, colour and taste } \\
\text { taste }\end{array}$ & $\begin{array}{l}\text { Haram and not allowed for ibadah (religious) purposes and also daily } \\
\text { purposes likes cooking and washing }\end{array}$ \\
\hline Water Application (Purpose) & $\begin{array}{l}\text { Harus and allowed for agricultural and farming purposes and also for fire } \\
\text { extinguish }\end{array}$ \\
\hline
\end{tabular}

Source: Istajib and Raihanah (2012)

Next, water also cannot be used if there are any najaasat mixed into it.

\subsection{Al-Mutahhirat (The Purifier)}

Before the water treatment and purification methods discussed at the next topic, it is needed to know the common purifier (Al-Mutahhirat) or several objects that can be used to eliminate the najasah in Islam that can be concluded as below (Muhammad Jawad, 2000):

i. Mutlaq Water

It is tahir (pure) and mutahhir (can be purified others) by consensus.

ii. Other liquids

According to the Hanafi, any tahir liquid like vinegar and rose-water as mutahhir.

iii. Ground 

it.

Hanafi mazhab provided it is walked on or rubbed on the ground and the actual najasah is there by removed

iv. Sun

v. Al-Istihalah (transformation)

It is the changing of one substance to another likes the changing of deer's blood into musk. It results in purification by consensus.

vi. Fire

Hanafi said that the burning of najasah by fire purifies provided the actual najasah disappears. They consider najis clay as tahir when it is turned into fired clay and najis oil tahir when made into soap. The Shafi'i and the Hanbali mazhab observe that fire is not among the mutahhirat. They hold an extreme position in this regard and consider even the ash and smoke of a najis object as najis. While, the Maliki regard the ash as tahir and the smoke as najis.

\section{vii. Tanning}

Hanafi observed that tanning purifies the skin of a carcass and every other najis animal except pig skin. As to the skin of a dog, it becomes tahir by tanning and fit to be prayed on it. Shafie says the tanning is mutahhir except for the skin of the dog and the pig. Maliki and Hanbali do not consider tanning as mutahhir although Hanbali allow the use of a najis tanned skin where liquids are not involved, so that its use does not lead to the spread of najasah.

viii. Carding

Hanafi said that cotton is purified on being carded.

ix. Disposition

X. Rubbing

Hanafi said that semen if removed by rubbing does not require water because taharah is achieved by rubbing.

xi. Wiping

Hanafi observed that an object which has a polished surface likes iron, copper and gold becomes tahir solely by wiping and does not require water.

xii. Boiling

Hanafi stated that if najis oil or meat is boiled on fire, they become tahir.

\subsection{Water Treatment and Purification in Islam}

This part will discuss about the water purification method in the views of several fuqaha'.

\subsubsection{Imam Hanafi}

Imam Hanafi argues that the impure water becomes clean by running it. If there is unclean water in a vessel or container, then water is poured on it until it flows out of its sides and it becomes pure. Similarly, if there is any impure water in a pool or hole, then dig another hole even though it is close and drain the impure water into the channel between the two holes. So that all the water accumulates in one hole, then the water becomes pure. If the water comes back into impure water for a thing, then the same way can be done to purify it, by digging another hole and running it until it accumulates in one hole. Therefore, water that should not use to take for ablution (wudhu') when it is in stagnant condition, then it is permissible when the stagnant water is running in any way. In fact, if there is even a carcass in it or a urine beneath it, there is no sign that the water is flowing and it is known that the water is not in contact with the spring, then if it is flowing, the water becomes pure (Al-Zuhaily, 1994).

\subsubsection{Imam Maliki}

Al-Malikiyah said that purifying the contaminated water can be done by pouring mutlaq water on it until the impurities are disappear (Muhammad Jawad, 2000). Removing impurities from water is done if the impure water changes one of the properties of the pure water whether it smells, tastes or colors, then it is elevated when it is added (poured) water from something else to it or it is lifted by itself in addition to something added to the water. 
Then, all of that water would become pure with the erosion of the water being changed by adding water and lifting it up and returning it as it was.

\subsubsection{Imam Syafi'e}

When there is little water that becomes impure by contact with najasah, but does not occur any change in its nature, the Syafi'e says that if the water is collected enough two qullah, it is pure and purifies the impurities, it is good enough that it is mixed with pure water or impure water, and if it is separated it is still pure. If one has two or more containers and each one contains impure water, then the impure water is collected in one place up to two qullah, then the water is pure and purified (Muhammad Jawad 2000).

Al- Shirazi (1996) explained in book of al-Muhazzab, he said:

"If you want to purify the impure water then it must be observed (if the water is defiled by reason of taghayyur (change in color, smell or taste) while it is more than two qullah, then it is purified by the loss of the purifier by itself or (missing taghayayur) by adding to it another water, or (missing taghayayur) by throwing away some of it, because the impurities were caused by taghayyur (change of color, smell or taste) and it was disappeared."

Next, it is also mentioned by al-Nawawi (2009):

"If the water had lost its taghayyur by taking some of it, the remaining water must have enough two qullah. If the water is less than two qullah then it is impure"

\subsubsection{Imam Hambali}

According to Hambali, the water will not be pure with enough up to two qullah either by using the impure water and pure water because collecting impure waters does not make the water become pure. Likewise, a little pure water is impure with a touch of impure water. Therefore, if it is to be purified, it may be enough water to two qullah or to be spilled. According to the Shafi'e and Hambali, if water is in large quantity changed due to contact with najasah, then it can be purified by simply eliminating the change (Muhammad Jawad, 2000).

\subsubsection{Other views}

Mustafa Al-Khin, et al (2011) in his book Fiqh Al-Manhaji defined taharah as the free from all impurities whether in hissi (real) or ma'nawi forms. Water is the one of the medium for taharah in Islam.

According to Islam, water purification method is debated in fiqh books by previous and today fuqaha' (scholars). This method is also based on ijtihad and fatwa of fuqaha' because there is no specific and detail nas (script) about it either from Al-Quran or Al-Sunnah. The ijtihad mentions how its condition when mutanajjis water (mutated water) turns into mutlaq water (pure water) by stating the theory as follows (Al-Shirazi, 1996):

First Theory : The water conditions change on its own naturally (changing of time, sun and wind)

Second Theory: The condition of water when added the pure water to clean up and the najis is disappear from the water

Third Theory: The condition where the dirty water is washed by soil

These theories are based on observation of fuqaha to the people around them and according to the situation of that time. According to Shafi'e mazhab, the water quantity for two (2) qullah is equivalent to 270L of water. If the musta'mal water is collected and more than two (2) qullah, the water turns into mutlaq water.

While Majlis Ugama Islam Singapore (2014) also has issued about this water purification by stating that the water can be purified by removing out the najasah (impurities) from the water.

After a detailed study, in consultation with scientists and engineers, the Council of Leading Islamic Scholars (CLIS) in Saudi Arabia concluded in a special fatwa in 1978 that treated wastewater can theoretically be used even for wudhu and drinking, provided that it presents no health risk (CLIS, 1987). The fatwa had issued by Saudi House of Fatwa regarding wastewater treatment as follows:

According to the report set by the experts in this regard, a large amount of water would be deemed pure from any impurity if the impurity is removed, if more water is added to it, or if the impurity is eliminated by the passing of time, the sun, the wind, or any other cause that would remove it.

Impure water can be purified by using modern filtering techniques that are the best and most efficient methods for purifying water. Many additives are put in impure water to remove impurities, as attested to by water treatment experts. 
Therefore, the council believes that such water would be completely pure and it may be used for ritual purification and drinking as long as there are no negative consequences on people's health. If it is recommended that water not be drunken, it would be due to reasons of public health and safety and not Islamic law.

The council recommends avoiding using treated water for drinking purposes to avoid health problems and also in consideration of the negative public sentiment about this water. However, using this water for the irrigation of crops or park areas is permissible.

On the basis of the 1978 fatwa, wastewater reuse in Saudi Arabia expanded greatly. In 1995, the kingdom reused about 15 per cent of its treated wastewater for irrigating date palms and fodder such as alfalfa. Moreover, ablution water at the two holy mosques in Mecca and Medina is recycled for toilet flushing, thus conserving expensive desalinized sea-water (Faruqui, 2001)

The methods to cleanse impure water or mutaghayyir which has one of its characteristics changed of taste, colour or smell is by applying these three methods as follows (Wijayant \& Kaukab, 2019):

i. Thariqat An-Nazh by draining the impure water and leave clean water without any change by closing the fountain, disposing the things causing the water impure and then eliminate the taste, colour and smell that causing the changes of water. The water is at least 2 qullah.

ii. Thariqat Al-Mukatsarah by adding mutlaq water into the impure water to eliminate all the najasah and everything that makes the water changed.

iii. Thariqah Taghyir by changing the impure water with different traits so that the characteristics of the water return to their original state or named as istihalah

So, it can be seen that the study of the status of water discussed in the Turath book is very important because purifying with pure water is a must before performance of worship such as pray, tawaf, reciting the Quran and so on. In addition, Islam itself recommends that every Muslim keep his or her purity free from any najasah that can lead to various diseases.

\subsection{The Utilization of Treated Water}

Fatwa convened by Majlis Ulamak Indonesia (2010) mention the permission on the utilization of treated water or recycled water.

Next, fatwa from Darul Iftaa, USA by Mufti Ebrahim Desai also mention about the permission of utilization of sewage water as follow (Majlis Ugama Islam Singapura, 2014):

According to Central Highlands Water, sewage is define as wastewater from shower, bathtub, washing machine, dishwasher, kitchen sink and toilet and it isn't just from the toilet. Interestingly, sewage is actually 99.8\% water. The sewage is transported to the treatment plant by a series of pipes and pump stations. In other words, there is a flow of water which both pure and impure. If this flowing water in the pipes has no traces of impurity like there is no change in colour, smell or taste, the water will be tahir or pure (Al-Quduri \& Ahmad, 1997) and (Al-Kasani, 2005). But, according to Mufti Ibrahim Desai (Majlis Ugama Islam Singapura, 2014), if the sewage water does have traces of impurity in its colour, taste or smell, then it may proceed to recycle wastewater treatment process. The process of wastewater treatment is explained as follows (Renne, 2011):

i. Sewage first goes through advanced primary treatment in which water is separated from large particles, then enters sedimentation tanks where chemicals are used to make primary sludge settle to the bottom and scum rise to the top. Once the water is separated out, $80 \%$ of the solids have been removed and the wastewater is clean enough to be discharged to the ocean.

ii. In secondary treatment, bacteria are added to the wastewater to ingest organic solids and producing secondary sludge that settles to the bottom.

iii. Tertiary treatment filters the water to remove whatever solids remain and disinfects it with chlorine and also removes the salt. It is called recycled water and can be used for irrigation or industry.

iv. For Indirect Potable Reuse (IPR), recycled water that eventually becomes drinking water. Tertiary-treated water undergoes advanced water technology, then spends time in groundwater or surface water such as a reservoir before being sent to drinking water supplies. Advanced water technology first involves microfiltration that strains out any remaining solids.

Based on the processed above, analysis of the water purification process from Fiqh perspective is explained below:

i. The advanced primary treatment which the water goes through in stage one does not purify the water in terms of Fiqh. In order to become pure in Fiqh, the impure water must either: 
a) Mixed in a large body of pure water or two qullah (the surface area of which is approx. 225 square feet

b) Flow with pure water, or

c) Pure water must be poured into the impure water tank causing a significant over flow of water after the impurities are removed

All the three methods mentioned are required with the colour, taste and smell of the water must return to normality. At stage two and three, the water has still not met the Fiqh standards of purification, though it may be biologically clean. It should be noted that tahārah (purification) of water is only necessary for drinking, cooking, wudu', ghusl, and washing clothes. Tertiary-treated water may be used for irrigation, flushing (toilet) and so on. Tertiary-treated water for drinking water which spends time in groundwater or surface water such as a reservoir is tāhir because it is mixed with a large body of water.

\section{Conclusion}

Method of water purification and treatment as in line with shariah compliance is vital to be implemented as the taharah or cleanliness is a big matter in Islam and the main condition in worship.

\section{Acknowledgement}

Special acknowledgement and appreciation given to Registrar Office, UTHM for funded this research.

\section{References}

1. Abdelkadir Ismail Tayob, Hameda Deedat \& Azizir Rahman Patel (2015). Islamic Jurisprudence and Conditions for Acceptability of Reclamation of Wastewater for Potable Use by Muslim Users. Report to Water Research Commision: Gezina

2. Abdul Baqi, M. F. (1987). Al-Mu'jam al-Mufahras li Alfaz al-Qur'an al-Karim (The Dictionary of The Phrases of The Glorious Quran). Cairo: Dar al-Hadith.

3. Ahmad Zaharuddin, A. S. (2004). Nilai Pengurusan Air Secara Islam Dalam Komuniti Dalam Pascamodenism. (SIVIC 2004). Hotel City Bayview Langkawi.

4. Al-Hadith.

5. Al-Kasani, Abu Bakar ibn Mas‘ud. (2005). Badai‘ al-Sanai‘, Kaherah: Dar al-Hadith

6. Al-Nawawi, (2009) Al-Majmu' Syarah Al-Muhadzdzab: Tahqiq Dan Ta'liq: Muhammad Najib Al Muthi'i : Pustaka Azzam: Kajang

7. Al-Quduri, Ahmad bin Muhammad (1997). Mukhtasar Al-Quduri fi Fiqhi Hanafi. Darul Beirut, Lubnan: Darul Kutub al-Alamiah

8. Al-Quran

9. Al-Shirazi, Abu Ishaq Ibrahim bin Ali bin Yusuf (1996). Al-Muhazzab fi Fiqh al Imam al-Shafie. Vol 3. Dar al-Kutub al-'Ilmiyyah.

10. CLIS (Council of Leading Islamic Scholars) (1978). Judgement Regarding Purifying Wastewater: Judgement No. 64 on 25 Shawwal, 1398 AH Thirteenth meeting of the Council of Leading Islamic Scholars during the second half of the Arabic month of Shawwal, 1398 ah (1998), Taif. J. Islamic Res. 17, 40-41. Coe, M. D.

11. Faruqui, Naser I., Asit K. Biswas and Murad J. Bino (2011). Water Management in Islam. Tokto: IDRC/ UNU Press

12. Ibn Taimiyyah (1987). Ahkam al-Taharah. Beirut: Dar al-Kutub al-'Ilmiyyah.

13. Kirsten Exall \& Troy D. Vassos (2012). Integrated Urban Water Management: Water Use and Reuse. Handbook of Metropolitan Sustainability

14. Majlis Agama Indonesia (2010). Air Daur Ulang. Fatwa Majelis Ulama Indonesia. No 2 (2010). https://mui.or.id/produk/infografis/26972/air-daur-ulang/

15. Majlis Ugama Islam Singapura (2014). Frequently Asked Question: Usage of Bone China. Accessed from http://www.muis.gov.sg/.

16. Mohd Istajib Mokhtar \& Raihanah Ismail (2012). Islamic Law of Water: Comparative Analysis of the Quality Aspects of Water. Jurnal Syariah. Jil 20. Bil 2. 187-220.

17. Muhammad Jawad Mughniyah. (2000). Fiqih Lima mazhab: Ja'fari, Hanafi, maliki, Syafi'i, Hambali. Jakarta: Lentera. P.p. 9-11.

18. Mustafa al-Khin et al. (1989). Al-Fiqh al-Manhaji ‘ala Madhhab al-Imam al-Syahi'i. volume 1. Damsyik: Darul; Ulum al-Insaniyyah

19. Mustofa Al-Khin, Mustofa Al-Bugho \& Ali Asy-Syarbaji (2011). Al-Fiqh Al-Manhaji Mazhab Al-Syafie. Terj oleh Dr Zulkifli Al-Bakri. Jilid 1. JAKIM: Malaysia

20. Nooh Gadot (2002). Konsep Air Dalam Islam. Presented in ‘Air Anugerah Tuhan' conference. Institut Kefahaman Islam Malaysia (IKIM), Kuala Lumpur. 
21. Ranhill Consulting Sdn Bhd (2011). Review of the National Water Resources (2000-2050) and Formulation of National Water Resources Policy. Volume 2. Water Resources Governance. Final Report

22. Renne, Cho (2011). https://blogs.ei.columbia.edu/2011/04/04/from-wastewater-to-drinking-water/.

23. Umar Abdul Jabbaar (2015). Elements of Shafiee Fiqh. Translated by Abdul Kareem. Jaamia Hamidia Educational Institute

24. Wahbah al-Zuhaili (1994). Fiqh dan Perundangan Islam. (Penterjemah: Syed Ahmad Syed Hussain et al). Jilid 1. Pustaka Perdana: Dewan Bahasa dan Pustaka, Kuala Lumpur

25. Wahbah al-Zuhaily (1985). al-Fiqh al-Islami Wa Adillatuh. Damsyik: Dar al-Fikr

26. Walid A. Abderrahman (2000). 'Application of Islamic Legal Principles for Advanced Water Management' in Water International. 25/4 (2000). 514

27. Walid A. Abderrahman (2000). Water Demand Management and Islamic Water Management Principles: A Case Study. International Journal of Water Resources Development. Volume 16. Issue 4. P 465-473

28. Wijayant, R., \& Kaukab, M. E. (2019). Istihalah Issue of Halal Food, Medicine and Cosmetics. Islamic, Social, Economics and Development (JISED), 4(19), 203-213. 